\title{
PEMBAGIAN HARTA WARISAN ORANGTUA YANG BERBEDA AGAMA DALAM PERSPEKTIF HUKUM ISLAM
}

\author{
Deddy Nur Cahyono \\ Fakultas Hukum, Universitas Airlangga \\ e-mail: deddynurcahyono24@gmail.com \\ Brama Adi Kusuma \\ Fakultas Hukum, Universitas Airlangga \\ e-mail: deddynurcahyono24@gmail.com \\ Jose Enrico Ickx Telussa \\ Fakultas Hukum, Universitas Airlangga \\ e-mail: deddynurcahyono24@gmail.com
}

\begin{abstract}
ABSTRAK
Salah satu penghalang tidak saling mewarisi menurut hukum waris Islam adalah perbedaan agama antara pewaris dengan ahli waris. Penghalang mewarisi ialah keberadaan penghalang yang menggugurkan hak seseorang untuk mewarisi harta peninggalan. Namun ketiadaan penghalang bukan berarti harus memberikan hak waris kepada seseorang. Dengan kata lain, yang dimaksud dengan penghalangpenghalang mewarisi ialah tindakan atau hal-hal yang dapat menggugurkan hak seseorang untuk mewarisi harta peninggalan setelah adanya sebab-sebab mewarisi. Seperti karena ia pembunuh atau sebab berbeda agama. Orang semacam ini disebut sebagai orang yang diharamkan mendapatkan warisan, keberadaannya dianggap bagaikan tidak ada, dan dia tidak dapat menghalangi ahli waris yang lainnya. Dalam Kompilasi Hukum Islam (KHI) saja tidak ada mengatur tentang wasiat wajibah bagi orang yang berbeda agama.
\end{abstract}

Kata Kunci: pembagian; harta warisan; berbeda agama

\begin{abstract}
One barrier is not mutually inherit according to Islamic inheritance law is the difference of religion between the heir with the beneficiary.The barrier is inherited is the existence of the barrier which has waived the right of a person to inherit treasure relics.But the absence of the barrier does not mean having to give the inheritance to someone.In other words, is the barrier-the barrier is inherited is the actions or things that could disqualify a person's right to inherit property remains after the inherited causes.Like a killer because he has a different religion or cause. Such a person is referred to as a prohibited person get heritage, its existence is considered like a nothing, and he could not mengahalangi the other heirs. In the Compilation of Islamic Law (KHI) only no probate wajibah set about to people of different religions.
\end{abstract} Keywords: division; inheritance; different religions

\section{PENDAHULUAN}

Naluriah manusia yang menyukai harta benda tidak jarang memotivasi seseorang untuk menghalalkan berbagai cara untuk mendapatkan harta benda tersebut, termasuk di dalamnya terhadap

harta pewarisnya sendiri. Disebutkan pengertian harta peninggalan menurut Pasal $171 \mathrm{~d}$ Kompilasi Hukum Islam (selanjutnya disingkat KHI) adalah harta yang ditinggalkan oleh pewaris baik yang 
berupa harta benda yang menjadi miliknya maupun hak-haknya. Harta waris menurut Pasal 171 e KHI adalah harta bawaan ditambah bagian dan harta bersama setelah digunakan untuk keperluan pewaris selama sakit sampai meninggalnya, biaya pengurusan jenazah (tajhiz), pembayaran utang, dan pemberian untuk kerabat.

Salah satu penghalang tidak saling mewarisi menurut hukum waris Islam adalah perbedaan agama antara pewaris dengan ahli waris. Penghalang mewarisi ialah keberadaan penghalang yang menggugurkan hak seseorang untuk mewarisi harta peninggalan. Namun ketiadaan penghalang bukan berarti harus memberikan hak waris kepada seseorang. Dengan kata lain, yang dimaksud dengan penghalang-penghalang mewarisi ialah tindakan atau hal-hal yang dapat menggugurkan hak seseorang untuk mewarisi harta peninggalan setelah adanya sebab-sebab mewarisi.

Ahli waris yang dilarang mendapatkan hak waris adalah seseorang (ahli waris) yang mempunyai sebab mewarisi, tetapi ia melakukan tindakan yang dapat menggugurkan kelayakan mewarisi. Seperti karena ia pembunuh atau sebab berbeda agama. Orang semacam ini disebut sebagai orang yang diharamkan mendapatkan warisan, keberadaannya dianggap bagaikan tidak ada, dan dia tidak dapat mengahalangi ahli waris yang lainnya. Yang telah disepakati para ulama sebagai penghalang-penghalang mewarisi dimasukkan dalam 3 (tiga) kelompok yaitu: 1. Berlainan agama; 2. Perbudakan; 3. Pembunuhan.

Banyaknya permasalahan apabila seseorang yang berbeda agama mendapatkan harta warisan dari orang muslim, para ahli fikih telah bersepakat berlainan agama antara orang yang mewarisi dengan orang yang mewariskan, merupakan salah satu penghalang dari beberapa penghalang mewarisi. Sehingga non muslim tidak bisa mewarisi harta muslim dan seorang muslim tidak dapat mewarisi harta non muslim. Sabda Nabi Muhammad SAW sebagai berikut: "Orang Islam tidak punya hak waris atas orang kafir, dan orang kafir tidak punya hak waris atas orang Islam".2

${ }^{1}$ Komite Fakultas Syariah Universitas Al Azhar. (20002001). Ahkamul-Mawarist fil-Fiqhil-Islami. Mesir: Penerbit Maktabah ar-Risalah ad Dauliyyah, h. 46.

${ }^{2}$ Moh. Machfudin Aladip. Terjemah Bulughul Maram. Karya Besar Alhafizh Ibn Hajar Al-Asqoalani. Semarang: Karya Toha Putra, h. 479.
Persoalan yang muncul dalam Hadits di atas adalah jika pewaris tersebut awalnya beragama non muslim, kemudian ia beragama Islam. Tapi, setelah kematian si pewaris tersebut harta peninggalanya belum dibagi-bagikan. Lantas, bagaimana dengan ahli warisnya? Hadits Nabi yang berbunyi: "Tidak dapat saling mewarisi dua ahli waris yang berbedabeda." (Hadis diriwayatkan oleh Imam Empat, kecuali Imam Turmudzi).

Pengamalan dari keumuman hadits di atas, bila seseorang mati meninggalkan anak laki-laki yang non muslim dan paman muslim, niscaya harta peninggalan si mayit semuanya diberikan paman, sehingga anak laki-laki yang non muslim tidak mendapatkan apaapa dari warisan ayahnya. Begitu juga sebaliknya, bila seorang non muslim meninggalkan anak lakilaki yang muslim dan paman yang non muslim, maka seluruh harta peninggalan diwariskan kepada paman yang non muslim, dan anak laki-laki si mayit yang muslim tidak mendapatkan apa-apa dari harta peninggalan ayahnya karena berlainan agama, antara anak dan orangtua. ${ }^{3}$

Para ahli fikih bersepakat bahwa non muslim dapat saling mewarisi satu sama lain ketika mereka berada pada satu kepercayaan, misalnya mereka sama-sama beragama Nasrani. Hal ini berdasarkan sabda Nabi SAW, "Orang Islam tidak boleh mewarisi harta orang kafir," hadits ini memiliki arti bahwa non muslim dapat saling mewarisi satu sama lain. Hukum ini merupakan ketetapan kebanyakan ahli fikih. Seperti kasus sengketa warisan yang telah diputus oleh Mahkamah Agung RI No. 51 K/AG/1999. Ahli waris non muslim dapat saja menikmati harta warisan muslim dengan cara pemberian wasiat wajibah.

Dalam KHI saja tidak ada mengatur tentang wasiat wajibah bagi orang yang berbeda agama. Wasiat wajibah yang terdapat dalam KHI hanya mengatur tentang anak angkat dan orangtua angkat, yang bunyinya adalah sebagai berikut:

1. Harta peninggalan anak angkat dibagi berdasarkan pasal-pasal 176 sampai dengan 193 tersebut di atas, sedangkan terhadap orangtua angkat yang tidak menerima wasiat diberi wasiat wajibah sebanyak-banyaknya $1 / 3$ dari harta warisan anak angkatnya.

\footnotetext{
${ }^{3}$ Ramlan Yusuf Rangkuti. (1987). Pengantar Hukum Islam.
} Medan: Fak. Hukum USU-UISU, h. 29. 
2. Terhadap anak angkat yang tidak menerima wasiat diberi wasiat wajibah sebanyakbanyaknya $1 / 3$ dari harta warisan orangtua angkatnya.

Anak angkat dan orangtua angkat dalam KHI tersebut di atas seimbang dengan kedudukannya pergantian tempat dalam KHI, yang bunyinya sebagai berikut: 1 . Ahli waris yang meninggal lebih dahulu dari pada si pewaris maka kedudukannya dapat digantikan oleh anaknya, kecuali mereka yang tersebut dalam Pasal 173; 2. Bagian ahli waris pengganti tidak boleh melebihi dari bagian ahli waris yang sederajat dengan yang diganti.

\section{PERUMUSAN MASALAH}

Penulisan artikel ini dimaksudkan untuk mengetahui kedudukan hak ahli waris yang berbeda agama dengan pewaris muslim, serta bagian harta ahli waris yang diterima oleh ahli waris yang berbeda agama dengan pewaris muslim melalui wasiat wajibah.

\section{PEMBAHASAN}

\section{Makna Wasiat}

Wasiat adalah pesan seseorang untuk memberikan suatu materi yang hanya dapat dimiliki, setelah pemberi wasiat tersebut meninggal dunia. Contohnya, seseorang berwasiat dengan akad, "jika saya meninggal dunia, sepeda motor ini menjadi milikmu". Wasiat memiliki ketentuan nominal yang diperbolehkan oleh syariat Islam, yaitu maksimal $1 / 3$ dari total harta warisan yang ditinggalkan. Jika wasiat tersebut melebihi ketentuan, yang dapat dibagi menjadi wasiat hanyalah sepertiga itu saja dan kelebihannya menjadi harta waris.

Kata wasiat berasal dari bahasa Arab, secara etimologi mempunyai beberapa macam arti, antara lain: 1. Menjadikan, artinya; Aku menjadikan harta untuk si fulan; 2. Menaruh kasih sayang, artinya; Aku menaruh kasih sayang untuk puteranya; 3. Menyuruh, artinya; Aku menyuruhnya untuk mengerjakan shalat; 4. Menghubungkan. ${ }^{4}$

Definisi wasiat di atas dapat ditarik suatu kesimpulan bahwa wasiat adalah merupakan penyerahan harta atau suatu hak secara sukarela dari seseorang kepada pihak lain yang berlaku setelah

${ }^{4}$ Zainuddin Ibn Abd al- Aziz. (1979). Fath al-Mu in, Terj. Ali as ad. Kudus: Menara Kudus, h. 393. orang tersebut meninggal dunia. Disinilah perbedaan antara perpindahan kepemilikan harta dengan jalan wasiat dan perpindahan kepemilikan harat secara jual beli, sewa menyewa, hibah, dan lain sebagainya.

Perbedaan tersebut pada akad tentang cara pemindahan harta tersebut. Meskipun akad wasiat dibuat pada saat si pemberi wasiat masih hidup, tapi menurut hukumnya wasiat tersebut baru dilaksanakan setelah orang yang berwasiat meninggal dunia. Artinya, selama si pewasiat masih hidup, wasiat itu tidak dapat dilaksanakan dan akad wasiat tersebut tidak mempunyai efek apapun bagi perpindahan hak milik kepada orang yang diberi wasiat, sedangkan pada akad jual beli, hibah, serta sewa menyewa akadnya serta merta tanpa harus menunggu pihak penjual, penghibah atau yang menyewakan meninggal dunia terlebih dahulu.

\section{Dasar Hukum Wasiat}

Dasar hukum wasiat dalam syari'at Islam, menurut para ahli fikih antara lain:

\section{Dalil dalam Al-Quran}

Kewajiban bagi seseorang yang akan meninggal dunia untuk menyampaikan wasiat kepada ibu dan bapak atau kaum kerabat lainnya dapat ditemukan ketentuannya dalam Al-Qur'an Surat Al-Baqarah ayat 180: "Diwajibkan atas kamu, apabila seorang di antara kamu kedatangan (tanda-tanda) maut, jika ia meninggalkan harta yang banyak, berwasiat untuk ibu bapak dan karib kerabatnya secara ma'ruf (ini adalah) kewajiban atas orang-orang yang bertakwa."

Ayat ini memberikan penegasan bahwa seseorang yang hendak (akan) meninggal dunia mestilah ia meninggalkan wasiat menyangkut harta yang ia miliki, ayat ini juga dapat dijadikan sebagi dasar hukum (wajibnya) wasiat wajibah, terutama sekali kepada ahli waris yang penghubungnya dengan pewaris terputus, sehingga mereka menjadi terdinding disebabkan oleh ahli waris yang lain, seperti kasus cucu yang terdinding untuk mendapatkan harta warisan dari datuk (kakeknya) dikarenakan oleh pamannya (saudara kandung ayahnya) masih ada.

Surat Al-Maidah ayat 106, artinya: "Hai orangorang yang beriman apabila salah seorang kamu menghadapi kematian sedang dia akan berwasiat,

\footnotetext{
${ }^{5}$ Yayasan Penyelenggara Penterjemah Al-Quran. (1980). Al-Quran dan Terjemahannya. Jakarta: Departemen Agama RI, h. 44 .
} 
maka hendaklah wasiat itu disaksikan oleh dua orang saksi yang adil di antara kamu, atau dua orang yang berlainan agama dengan kamu jika kamu dalam perjalanan di muka bumi lalu ditimpa bahaya kematian."

Surat Al-Baqarah ayat 240, artinya: "dan orangorang yang akan meninggal dunia diantaramu dan meninggalkan isteri, hendaklah berwasiat untuk isteri-isterinya (yaitu) diberi nafkah hingga setahun lamanya dengan tidak disuruh pindah (dari rumahnya), akan tetapi jika mereka pindah (sendiri) tidak ada dosa bagimu (wali atau ahli waris dari yang meninggal) membiarkan mereka berbuat yang ma'ruf terhadap diri mereka."

\section{Sunnah}

Hadist riwayat Bukhari dan Muslim dari Ibnu Umar, artinya: Rasulullah SAW bersabda: "Bukanlah hak seorang Muslim yang mempunyai sesuatu yang ingin diwasiatkan bermalam (diperlambat) selama dua malam, kecuali wasiatnya telah dicatat di sisiNya." (HR. Bukhari Muslim). Artinya: Rasulullah SAW bersabda: "Barangsiapa meninggal dan berwasiat, maka ia mati pada jalan dan sunnah, meninggal pada jalan taqwa dan persaksian dan juga meninggal dalam keadaan diampuni (dosadosanya)."

\section{Syarat dan Rukun Wasiat}

Wasiat dalam pandangan hukum Islam ada aturannya, ada wasiat yang dibenarkan dan ada pula wasiat yang tidak dibenarkan hukum Islam. Adapun, wasiat yang dibenarkan adalah wasiat yang diperuntukkan kepada selain ahli waris karena Nabi SAW melarang pemberian wasiat harta kepada ahli waris untuk mencegah ketidakadilan dalam hadis yang artinya ahli waris tidak boleh menerima wasiat.

\section{Yang Berhak Menerima Wasiat}

Penerima wasiat adalah semua orang yang tidak tergolong sebagai ahli waris yang mendapatkan harta waris. Oleh karena itu, seorang ahli waris yang jauh dan tidak mendapatkan harta waris akibat terhalang oleh ahli waris yang lebih dekat, berhak mendapatkan harta dengan jalan wasiat. Menurut ulama dari

\footnotetext{
6 ibid., h. 181.

${ }^{7}$ ibid., h. 59.
}

kalangan Mazhab Hanafi bagi orang yang menerima wasiat harus mempunyai syarat-syarat antara lain:

1. Mempunyai keahlian memiliki, jadi tidak sah wasiat kepada orang yang tidak bisa memiliki.

2. Orang yang menerima wasiat itu masih hidup ketika dilangsungkannya ijab wasiat, meskipun dalam perkiraan.

3. Orang yang menerima wasiat itu tidak melakukan pembunuhan kepada orang yang memberi wasiat, baik pembunuhan yang disengaja maupun tidak disengaja.

Para ulama telah sepakat tentang sahnya wasiat kepada anak yang masih dalam kandungan, dengan syarat bahwa ia lahir dalam keadaan hidup, dan sepakat tentang sahnya wasiat untuk kepentingankepentingan umum, akan tetapi terdapat perbedaan pendapat dalam hal si penerima wasiat meninggal terlebih dahulu dari pada si pemberi wasiat, mengenai hal ini mazhab yang empat (Syafi'iyah, Hanabilah, Malikiyah, Hanafiyah) sepakat bahwa apabila telah mati, maka wasiat itu batal, sebab wasiat adalah pemberian, sedangkan pemberian kepada orang yang mati adalah tidak sah.

\section{Barang yang Diwasiatkan}

Harta wasiat adalah sejumlah harta yang diwasiatkan untuk diberikan kepada selain ahli waris dan tidak melebihi sepertiga dari seluruh warisan. Harta wasiat wajib dibayarkan dan dikeluarkan sebelum pembagian warisan dilaksanakan. Harta warisan merupakan jalan keluar dalam memberi harta kepada orang lain yang bukan ahli waris setelah meninggal dunia. Dengan berwasiat, harta bisa diberikan kepada orang lain yang bukan ahli waris setelah pemilik harta meninggal dunia.

Anak tiri atau anak angkat tidak memiliki hak waris dari orangtua tiri atau angkatnya. Dengan adanya wasiat, anak tiri dan anak angkat bisa mendapatkan harta peninggalan orangtua tiri dan angkatnya. Demikian juga dengan orang lain yang memiliki kedekatan dengan seseorang, bisa mendapatkan harta orang tersebut setelah dia meninggal dengan jalan wasiat.

\section{Hukum Berwasiat Bagi Orang Lain}

Berwasiat bagi seorang muslim bukanlah suatu keharusan. Namun, Rasulullah SAW menganjurkan agar seseorang itu berwasiat yang baik, sebelum 
dirinya meninggal dunia. Perhatikan hadis berikut ini: "Jika seorang muslim itu ingin mewasiatkan sesuatu, hendaklah dia menuliskan wasiat itu dalam waktu 2 x 24 jam, yakni segera mungkin." (HR. Muslim).

Berwasiat sebelum meninggal adalah hal yang dianjurkan. Berwasiat untuk mewakafkan sebagian harta yang akan ditinggalkan juga merupakan hal yang sangat baik dan positif. Namun, demikian yang harus diperhatikan juga adalah kadar wasiat yang akan diwakafkan tidak boleh melebihi sepertiga bagian dari seluruh harta kekayaan yang akan ditinggalkan. Kadar maksimal dari harta yang boleh diwasiatkan untuk wakaf adalah sepertiga saja. Jika total harta warisan adalah Rp.900, yang dapat diwakafkan dengan jalan wasiat adalah Rp.300 saja.

Wasiat yang hukumnya wajib adalah wasiat yang menetapkan tugas menyampaikan hak-hak kepada pemiliknya, seperti berwasiat dengan barang-barang titipan, hutang-hutang. Wasiat seperti itu diperkirakan mewajibkan untuk mengembalikan barang-barang tadi kepada pemiliknya, sebab jika tidak diwasiatkan dan kemudian orang yang bersangkutan meninggal, maka barang-barang tadi akan hilang dari pemiliknya, akhirnya orang tadi akan berdosa karena sikap perbuatannya.

Wasiat yang hukumnya haram adalah wasiat untuk suatu motif kejahatan, maksiat, maka wasiat seperti ini dianggap batal, dan tidak harus dikerjakan oleh orang yang menerima wasiat.

Wasiat yang hukumnya makhruh adalah wasiat yang melebihi $1 / 3$ harta yang dimiliki. Wasiat yang hukumnya sunnah adalah wasiat dengan hak-hak Allah, seperti wasiat dengan kifarat-kifarat, zakat, fidayah puasa atau berwasiat untuk menunaikan ibadah haji serta ibadah-ibadah taqqarub lainnya.

Wasiat yang mubah adalah berwasiat kepada orang-orang kaya dari lingkungan keluarga dan kerabat atau dari selain mereka, adapun wasiat yang makhruh ialah wasiat kepada orang-orang yang melakukan perbuatan fisik dan kemaksiatankemaksiatan.

Ulama Mazhab Maliki membagi hukum wasiat kepada lima, yaitu: 1. Wasiat wajib, yaitu wasiat bagi orang yang mempunyai hutang atau yang memiliki barang titipan; 2. Wasiat yang haram, yaitu berwasiat dengan perbuatan yang haram seperti berwasiat untuk meratapi mayit; 3. Wasiat yang sunnah yaitu berwasiat dengan ibadah taqarrah yang wajib; 4. Wasiat yang makhruh yaitu wasiat yang dilakukan seseorang yang memiliki harta yang sedikit sementara ia mempunyai ahli waris; 5 . Wasiat yang mubah, yaitu berwasiat dengan segala sesuatu yang hukumnya mubah. ${ }^{8}$

Ulama Mazhab Hambali membagi hukum wasiat menjadi lima, yaitu:

1. Wasiat yang wajib, yaitu wasiat yang bila tidak dilakukan membawa akibat hilangnya hakhak atau peribadatan, seperti berwasiat untuk melunasi hutang, demikian juga berwasiat bagi orang yang sudah memiliki kewajiban untuk berzakat, haji, kifarat, atau nazar;

2. Wasiat yang sunnah, yaitu berwasiat kepada kerabat yang fakir yang tidak bisa mewarisi, dengan syarat orang yang berwasiat memiliki harta peninggalan yang banyak dan tidak melebihi seperlima harta;

3. Wasiat yang makhruh, yaitu wasiat dari orang yang tidak memiliki harta yang banyak, sedangkan ia memiliki ahli waris yang sangat membutuhkannya;

4. Wasiat yang haram, yaitu wasiat yang melebihi sepertiga harta, haram bagi orang yang mempunyai ahli waris untuk berwasiat melebihi sepertiga harta kecuali suami atau isteri;

5. Wasiat yang mubah, yaitu wasiat selain dari wasiat yang telah disebutkan di atas. ${ }^{9}$

Larangan berwasiat kepada ahli waris yang telah ditentukan pembagian warisannya, menurut para ahli fikih agar tidak ada kesan bahwa wasiat itu menunjukkan perbedaan kasih sayang antara seama ahli waris, yang pada akhirnya dapat menyulut perselisihan di antara ahli waris yang ditinggalkan oleh si pewaris.

Keluarga Rasulullah SAW menyatakan bahwa seseorang tidak boleh berwasiat kepada ahli warisnya yang mendapat pembagian warisan, kecuali apabila diizinkan oleh ahli waris yang lainnya.

Sebagian ulama yang lain berpendapat boleh memberikan wasiat kepada ahli waris, terutama kepada yamg dipandang sangat membutuhkan. Seperti jika sebagian mereka itu kaya dan sebagian

${ }^{8}$ A. Sukris Sarmadi. (1997). Transendensi Keadilan Hukum Waris Islam Transformatif. Jakarta: Raja Grafindo Persada, h. 328.

9 ibid., h. 316. 
lagi miskin, maka layaklah apabila kepada si miskin selain dia mendapatkan warisan dia juga diberikan tambahan dengan jalan wasiat, atau kepada anak yang bapaknya telah menceraikan ibunya sementara ibunya tidak memiliki anggota keluarga yang lain selain anaknya itu.

\section{Batas Pelaksanaan Wasiat}

Mengenai jumlah besarnya harta yang diwasiatkan sesuai dengan hadis Rasulullah SAW bahwa wasiat hanya diperboleh sepertiga dari harta milik peninggalan si pewasiat. Para ulama sependapat bahwa orang yang meninggalkan ahli waris tidak boleh memberikan wasiat lebih dari sepertiga hartanya, dan jika melebihi sepertiga dari harta warisan, para ahli hukum semua mahzab sepakat bahwa hal itu harus ada izin dari para ahli waris, sekiranya semuanya mengizinkan maka sahsah wasiat itu, tetapi jika mereka menolak, maka selebihnya dari sepertiga itu adalah menjadi batal. ${ }^{10}$

Wasiat yang tidak dibenarkan dalam syariat Islam selain ditujukan kepada ahli waris juga wasiat harta yang nilainya lebih dari sepertiga seluruh harta warisan yang ditinggalkan. Jika ada seseorang yang harta warisannya Rp.900, lalu dia mewasiatkan hartanya Rp.500, wasiat ini tidak sah karena melebihi aturan sepertiga yang disyaratkan Islam. Namun, jika nilai wasiatnya Rp.300, tetap bisa dijalankan dan dibenarkan secara syariat.

\section{Kedudukan Wasiat Dalam Hukum Islam}

Firman Allah SWT dalam Al-Qur'an Surat An-Nisa ayat 11, artinya: "Setelah diambil untuk wasiat yang diwasiatkannya atau setelah dibayar utangnya." 11 Dari firman tersebut disimpulkan bahwa Allah SWT telah mewajibkan kepada umat Islam untuk mempusakakan harta peninggalannya kepada ahli warisnya dengan mewajibkan untuk mendahulukan pelaksanaan wasiat dan pembayaran hutang-hutang si mayit. Tujuannya adalah untuk memberikan dorongan atau motivasi agar setiap orang semasa hidupnya ketika datang kepadanya tandatanda kematian sangat dianjurkan agar berwasiat,

${ }^{10}$ Erik Sumarna. (2004). Wasiat Wajibah Terhadap Saudara Kandung. Medan: Program Pascasarjana IAIN Sumatera Utara, h. 54 .

${ }^{11}$ Yayasan Penyelenggara Penterjemah Al-Qur'an. op.cit., akan tetapi kewajiban yang lebih utama didahulukan adalah pelunasan hutang-hutang si mayit.

Secara prinsip, wasiat dalam sistem hukum kewarisan Islam mengandung makna yang sangat penting guna menangkal jika terjadinya kericuhan dan perpecahan dalam keluarga, karena tidak menutup kemungkinan akan adanya anggota keluarga yang emosional dalam pembagian harta warisan. Beda lagi dengan hubungan darah yang sangat dekat dengan si pewaris tetapi tidak berhak menerima harta peninggalan dengan jalan warisan, padahal telah cukup berjasa kepada almarhum pewaris apalagi bila dilihat dari sosial ekonomi sepenuhnya dialah yang berhak untuk menerima warisan tersebut.

\section{Kedudukan Wasiat Dalam KUHPerdata (Burgerlijk Wetboek)}

Wasiat dalam Kitab Undang-Undang Hukum Perdata (selanjutnya disebut KUHPerdata) diatur dalam Pasal 874-1022. Mereka yang dibenarkan untuk berwasiat, jika telah berumur sekurangkurangnya 18 tahun. Batasan jumlah harta maksimal $1 / 2$ harta jika pewasiat mempunyai seorang anak yang sah, 2/3 apabila memiliki dua orang anak yang sah, dan $3 / 4$ jika memiliki tiga orang anak yang sah termasuk dalam pengertian ini adalah "anak turun mereka sebagai pengganti anak dalam garis turun masing-masing." Dan maksimal $1 / 2$ jika pewasiat hanya meninggalkan ahli waris garis lurus ke atas, demikian juga terhadap anak luar kawin yang diakui telah sah. "kecuali tidak ada keluarga garis ke atas, pewasiatan tidak dibatasi". "Pengangkatan seseorang untuk dapat menjadi ahli waris sebagaimana hak para ahli waris lainnya dapat dilakukan dengan pewasiatan."

Pengangkatan seseorang untuk dapat menjadi ahli waris, maka berlaku untuknya hak mewarisi sebagaimana anak-anak pewaris dalam mewarisi. Suatu pewasiatan melebihi dari bagian yang telah ditentukan, maka jumlah bagian tersebut harus dipotong sesuai dengan apa yang seharusnya telah diatur sehingga jumlahnya tidak melebihi batas yang telah ditentukan. Pembatasan itu penting, misalnya terletak dalam pasal-pasal tentang legitieme portie.

Legitieme portie atau bagian mutlak adalah suatu bagian dari harta peninggalan yang harus diberikan kepada ahli waris dalam garis lurus menurut undangundang terhadap bagian mana orang yang meninggal 
dunia tidak diperbolehkan menetapkan sesuatu, baik selaku pembagian antara yang masih hidup, maupun selaku wasiat. ${ }^{12}$

Suatu testament, juga dapat berisikan legaat yaitu suatu pemberian kepada seseorang. Adapun yang dapat diberikan dalam suatu legaat dapat berupa: 1 . Satu atau beberapa benda tertentu; 2 . Seluruh benda dari satu macam atau jenis, misalnya seluruh benda yang bergerak; 3. Hak atas sebagian atau seluruh harta warisan; 4. Sesuatu hak lain terhadap budel misalnya hak untuk memberi satu atau beberapa benda tertentu dari budel. ${ }^{13}$

Orang yang menerima suatu legaat, dinamakan legataris, ia bukan ahli waris karena ia tidak menggantikan orang yang meninggal dunia dalam hak-hak dan kewajibannya (yang penting tidak diwajibkan membayar utang-utang orang yang meninggal dunia). Adakalanya seseorang legataris yang menerima beberapa benda diwajibkan memberikan salah satu benda itu kepada orang lain yang ditunjuk dalam testament."Apabila dalam suatu testament diberikan suatu benda yang tadi dapat dibagi-bagi, mialnya seekor kuda kepada kedua orang bersama-sama dan kemudian salah seorang meninggal dunia maka benda itu jatuh kepada temannya yang masih hidup untuk seluruhnya."

Pasal 931 BW mengenal tiga macam atau jenis cara pembuatan surat wasiat, yaitu: 1 . Surat wasiat yang ditulis sendiri (olografis) Pasal 932 BW; 2. Surat wasiat tak rahasia/akta umum (openbaar) Pasal 938 BW; 3. Surat wasiat rahasia/tertutup (geheim) Pasal 940 BW. Ketiga jenis surat wasiat tersebut di atas harus dibuat dihadapan Notaris yang berwenang.

Surat wasiat Olografis, oleh BW diatur dalam Pasal 932 dan seterusnya. Dalam ketentuannya, surat wasiat ini seluruhnya harus ditulis dan ditanda tangani oleh si pewaris dan kemudian disimpan oleh Notaris, pada waktu menyimpan haruslah dihadiri oleh dua orang saksi, dan wajib membuat sebuah akta penyimpanan yang hanya ditandatanganinya bersama-sama dengan si yang mewariskan dan saksisaksi, akta mana harus ditulis, baik di bawah surat

\footnotetext{
${ }^{12}$ R. Subekti dan R. Tjitrisudibio. (1960). Kitab UndangUndang Hukum Perdata. Jakarta: Paramita, h. 21.

13 M. Idris Ramulyo. (1992). Perbandingan Hukum Kewarisan Islam Menurut Undnag-Undang Hukum Perdata (BW) di Pengadilan Negeri (Suatu Studi Kasus). Jakarta: Pedoman Ilmu Jaya, h. 111.
}

wasiat, jika surat ini dengan terbuka disampaikannya kepadanya, maupun di atas kertas tersendiri.

Mengenai surat wasiat tak rahasia ini, diatur dalam pasal-pasal 938 BW dan seterusnya. Menurut Pasal 938 BW menentukan bahwa tiap-tiap surat wasiat dengan akta umum harus dibuat dihadapan Notaris dan dihadiri oleh dua orang saksi.

Syarat-syarat pembuatan surat wasiat rahasia ini diatur dalam Pasal 940 BW dan 941 BW. Pembuatan surat wasiat rahasia atau tertutup haruslah dibuat sendiri dan ditandatanganinya dan dimasukkan dalam sampul yang disegel untuk selanjutnya diserahkan kepada Notaris dengan dihadiri oleh 4 (empat) orang saksi.

\section{Wasiat Wajibah}

\section{Pengertian wasiat wajibah}

Pengertian wasiat wajibah yang akan diuraikan berbeda dengan pengertian wasiat yang telah diuraikan terdahulu. Wasiat wajibah yang diuraikan ini adalah wasiat wajibah sebagai hak yang diperoleh ahli waris yang terhalang untuk memperoleh warisan.

Wasiat wajibah merupakan kata majemuk yang terdiri dari dua kata, yaitu wasiat dan wajibah, bila kata tersebut berdiri sendiri maka makna yang dimilikinya akan masing-masing pula. Begitu juga bila digabungkan akan membentuk arti tersendiri pula. Peneliti tidak lagi membahas pengertian wasiat karena sudah dibahas pada Bab II di atas. Peneliti lebih fokus untuk membahas tentang wajibah.

Pengertian wajibah mengandung makna bahwa wasiat yang pelaksanaannya tidak dipengaruhi atau tidak tergantung kepada kemauan atau kehendak si pewasiat yang meninggal dunia. Di mana pelaksana wasiat tersebut tidak memerlukan bukti bahwa wasiat tersebut diucapkan, atau ditulis, atau dikehendaki, tapi pelaksanaannya didasarkan kepada alasan-alasan hukum yang membenarkan bahwa wasiat tersebut harus dilaksanakan. ${ }^{14}$

Dikatakan wasiat wajibah disebabkan dua hal: 1 . Hilangnya unsur ikhtiar bagi yang memberi wasiat dan munculnya unsur kewajiban melalui perundangundangan atau surat keputusan tanpa tergantung kepada orang yang berwasiat dan keputusan si penerima wasiat; 2. Adanya kemiripan dengan

${ }^{14}$ Suparman Usman. (2001). Hukum Islam. Jakarta: Gaya Media Pratama, h. 163. 
ketentuan pembagian harta pusaka dalam penerimaan laki-laki dua kali lipat bagian perempuan.

Wasiat wajibah adalah hasil kompromi pendapatpendapat Ulama Salaf dan Ulama Khalaf, yaitu:

1. Tentang kewajiban berwasiat kepada kerabatkerabat yang tidak dapat menerima pusaka ialah diambil dari pendapat fuqaha dan tabi'in besar ahli fiqih dan ahli hadist, antara lain Said Ibnu Mussayab, Hasanul Bishry, Thawus, Imam Ahmad, Ishaq bin Rahawih dan Ibnu Hazm.

2. Pemberian sebagian harta peninggalan si mati kepada kerabat-kerabat yang tidak dapat menerima pusaka yang berfungsi sebagai wasiat wajibah, bila si mati tidak berwasiat adalah diambil dari pendapat Ibnu Hazm yang dikutip dari fuqaha, tabi'in dan dari pendapat mazhab Imam Ahmad.

3. Pengkhususan kerabat-kerabat yang tidak dapat menerima pusaka kepada cucu dan pembatasan penerimaan kepada 1/3 (sepertiga) peninggalan adalah didasarkan kepada pendapat Ibnu Hazm dan berdasarkan kaidah syariah: "Pemegang kekuasaan mempunyai wewenang memerintahkan perkara yang mubah, karena ia berpendapat bahwa hal itu akan membawa kemaslahatan umum. Bila penguasa memerintahkan demikian wajiblah ditaati".

Kitab Undang-Undang Hukum Wasiat Mesir dalam Pasal 78 mewajibkan pelaksanaan wasiat wajibah tersebut tanpa tergantung perizinan ahli waris walaupun si mati tidak mewasiatkannya, setelah dipenuhi perawatan dan pelunasan hutang dan wasiat wajibah tersebut harus didahulukan dari wasiat-wasiat lainnya. Artinya kalau ada sisa setelah pelaksanaan wasiat wajibah, baru dilaksanakan wasiat-wasiat yang lain menurut urutan yang telah ditentukan oleh undang-undang wasiat, baru kemudian dibagi-bagikan kepada ahli waris sesuai dengan bagian masing-masing. Sebesar yang diterima oleh orangtuanya sekiranya orangtuanya masih hidup dengan ketentuan tidak boleh melebihi 1/3 (sepertiga) peninggalan dan harus memenuhi dua syarat: 1. Cucu bukan termasuk orang yang berhak menerima pusaka, dan 2. Si mati (ayahnya) tidak memberikan kepadanya dengan jalan lain sebesar yang telah ditentukan kepadanya. ${ }^{15}$

\footnotetext{
${ }^{15}$ Fathur Rahman. (1994). Ilmu Waris. Bandung: Almaatif,
}

Menurut Ahmad Rofiq Wasiat Wajibah adalah wasiat yang dibebankan oleh hakim agar seseorang yang telah meninggal dunia yang tidak melakukan wasiat secara sukarela, harta peninggalannya dapat diambil untuk diberikan kepada orang tertentu dalam keadaan tertentu pula.

Penguasa atau hakim sebagai aparat negara mempunyai wewenang untuk memaksa atau memberi putusan wasiat wajibah kepada orang-orang tertentu misalnya berwasiat kepada ibu atau ayah yang beragama non muslim, sebagaimana diketahui bahwa perbedaan agama adalah menjadi penghalang untuk menerima warisan, sehingga dalam keadaan seperti itu ayah atau ibu tidak mungkin mendapatkan harta peninggalan dengan jalan wasiat wajibah.

\section{Wasiat wajibah dalam perspektif fikih}

Sebagian ulama berpendapat bahwa wasiat untuk kedua orangtua atau kerabat yang tidak menerima waris adalah wajib, apabila si mati tidak berwasiat untuk mereka, maka para ahli waris wajib mengeluarkan sejumlah harta tertentu dari harta si mati dan memberikannya kepada wasiat wajibah kepada mereka. Pendapat seperti ini dikemukakan oleh Ibnu Hazm dan Muhammad Rasyid Ridha. Perintah berwasiat ada dalam Al-Quran Surah AlBaqarah ayat 180, menurut Ibnu Hazm adalah wajib dan bersifat qada' $i$, artinya kalau seseorang tidak berwasiat maka kaum kerabat yang tinggal wajib untuk mengeluarkan sejumlah tertentu dari harta warisan, yang mereka anggap layak untuk kaum kerabat yang tidak berhak mewarisi, tapi pendapat ini berbeda dengan pendapat jumhur ulama yang memahami bahwa ayat wasiat ini telah dimansukh oleh ayat kewarisan.

Pandangan Ibnu Hazm di atas, menemukan suatu kewajiban hukum yang definitif bagi orang Islam untuk membuat wasiat yang akan didistribusikan kepada kerabat dekat yang bukan ahli waris. Selanjutnya ia berpendapat, jika orang yang meninggal gagal untuk memenuhi kewajiban ini ketika ia masih hidup, maka pengadilan harus membuat wasiat atas namanya.

Berbeda dengan pendapat Rasyid Ridha, menurutnya wasiat dalam hukum kewarisan adalah khusus diberikan kepada orang-orang yang tidak dapat mewarisi karena sebab terhalang mewarisi walaupun berbeda agama, apabila masuk Islam 
seorang kafir kemudian datang kepadanya kematian. Sementara kedua orangtuanya masih tetap kafir, maka kepadanya diharuskan untuk berwasiat untuk melunakkan hati kedua orangtuanya, sebagaimana perintah Allah SWT untuk senantiasa berbuat baik kepada kedua orangtua walaupun kedua-duanya tetap kafir. ${ }^{16}$

Dari uraian di atas jelaslah bahwa kedua orangtua dan kerabat yang tidak bisa mewarisi disebabkan karena adanya salah satu penghalang, apakah karena perbudakan, beda agama atau terhijab oleh ahli waris lain, wajib diberi wasiat, apabila seorang muslim pada saat hidupnya tidak berwasiat. Namun perlu dijelaskan juga siapa yang dimaksud kerabat yang harus wasiat wajibah tersebut, Ibnu Hazm telah memberikan batasan bahwa yang dimaksud dengan kerabat adalah semua keturunan yang memiliki hubungan nasab seayah dan seibu sampai terus ke bawah. ${ }^{17}$

Persoalannya adalah untuk menentukan kerabat dekat yang akan menerima wasiat wajibah tersebut, Siapa dari kerabat terdekat yang akan menerima wasiat wajibah tersebut. Untuk menjawabnya diperlukan pendekatan dengan interpretasi, karena baik Al-Quran maupun Hadist membiarkan masalah fundamental ini tidak terjawab. Suatu interpretasi baru diajukan untuk pertama kali oleh para ahli hukum Mesir pada tahun 1946, yang menspesifik kerabat dekat tersebut kepada cucu yang orangtuanya telah meninggal terlebih dahulu (cucu yatim).

\section{Wasiat wajibah perspektif KHI}

Pasal 209 KHI telah menetapkan hubungan antara anak angkat terjalin hubungan yang saling berwasiat. Pasal ini menjelaskannya dalam ayat (1) dan ayat (2), bunyinya sebagai berikut:

1. Harta peninggalan anak angkat dibagi berdasarkan pasal-pasal 176 sampai dengan 193 tersebut di atas, sedangkan terhadap orangtua angkat yang tidak menerima wasiat wajibah diberi wasiat wajibah sebanyak-banyaknya $1 / 3$ (sepertiga) dari warisan anak angkatnya.

2. Terhadap anak angkat yang tidak menerima wasiat diberi wasiat wajibah sebanyak-

\footnotetext{
${ }^{16}$ Erik Sumarna. op.cit., h. 136.

${ }^{17}$ Mughniyah, dkk. (2004). Fiqih Lima Mazhab. Jakarta: Lentera, h. 588.
}

banyaknya $1 / 3$ (sepertiga) dari harta warisan orangtua angkatnya.

Ketentuan pasal di atas membuktikan bahwa KHI telah menentukan suatu hukum yang selama ini tidak dikenal dalam wacana fikih yang memberikan wasiat wajibah kepada anak angkat atau orangtua angkat, dan ini berbeda pula dengan konsep wasiat wajibah yang diterapkan di negara-negara Islam lainnya seperti di Mesir. Melihat wasiat wajibah dalam undang-undang kewarisan Mesir adalah ketentuan yang mengatur tentang perolehan harta seorang yang berstatus sebagai dzawil arham.

Dilakukan perbandingan dengan konsep KHI, maka konsep wasiat wajibah di Mesir hampir sama dengan konsep ahli waris pengganti dalam KHI, misalnya adalah seorang cucu yang terlebih dahulu ditinggal mati oleh ayahnya dinyatakan memperoleh harta warisan dari kakeknya untuk menggantikan kedudukan ayahnya, dan mengambil bagian ayahnya dengan ketentuan tidak lebih dari 1/3 (sepertiga) harta peninggalan, bukan menyangkut perolehan anak angkat.

Kedudukan cucu dalam KHI tersebut adalah menggantikan kedudukan ayahnya yang telah meninggal dunia dengan mendapatkan bagian tidak dapat melebihi dari bagian ahli waris yang masih hidup yang sejajar dengan kedudukan ayah yang digantikannya. Dalam KHI konsep seperti ini disebut dengan ahli waris pengganti. Dengan demikian ketentuan wasiat wajibah yang diatur dalam KHI berbeda dengan konsep wasiat wajibah di negara Mesir dan ini adalah merupakan ciri khas tersendiri hukum waris di Indonesia.

\section{Wasiat wajibah anak angkat menurut KHI}

Kedudukan anak angkat dan orangtua angkat dalam hukum kewarisan menurut KHI secara tegas telah diatur dalam Pasal 209 KHI. Secara umum dapat dikatakan bahwa status anak angkat dan orangtua angkat yang diatur dalam KHI tetap sebagaimana status asalnya, yaitu hanya mempunyai hubungan nasab dengan orangtua kandungnya sama dengan pendapat para ulama ahli fikih, karenanya dia hanya mempunyai hubungan waris dengan mereka. Dengan demikian terlihat bahwa pengangkatan anak tidaklah merubah status dan kedudukan serta hubungan nasab yang telah ada sebelumnya. 
Konsep pengangkatan anak seperti ini berbeda dengan konsep adopsi sebagaimana diatur dalam hukum positif yang berkembang saat ini yang menisbahkan anak angkat dengan orangtua angkatnya, sehingga di antara mereka bisa saling mewarisi.

KHI yang mengatur tentang orangtua angkat mewajibkan untuk berwasiat (wasiat wajibah) demi kemaslahatan anak angkatnya sebagaimana orangtua angkat telah menerima pembebanan tanggung jawab untuk mengurus dari segala kebutuhan anak angkatnya. Jadi meskipun anak angkat secara dalil naqli tidak mendapat harta peninggalan orangtua angkatnya, namun dari segi kemaslahatan terutama demi anak tersebut yang secara emosional dan sosial begitu dekat hubungannya dengan orangtua angkatnya, tanggung jawab orangtua angkat tetap ada. Maka status anak angkat adalah identik dengan orang miskin yang membutuhkan bantuan uluran orangtua angkatnya agar masa depannya terjamin, terutama dari segi ekonominya.

KHI konsisten sesuai dengan faraid yang menempatkan kedudukan anak angkat tetap ditempatkan di luar ahli waris, sama dengan pendapat di dalam fikih, namun dengan mengadopsi hukum adat secara terbatas kedalam nilai hukum Islam karena beralihnya tanggung jawab orangtua kandung kepada orangtua angkat mengenai pemeliharaan kehidupan sehari-hari.

Substansi lembaga wasiat termasuk didalamnya adalah lembaga wasiat wajibah yaitu suatu wasiat yang harus dianggap telah ada, baik telah terucap, tertulis, atau sama sekali belum terucap maupun tertulis oleh orangtua angkat kepada anak angkatnya, ataupun sebaliknya dari anak angkat terhadap kedua orangtua angkatnya mengenai harta peninggalannya, maka dianggap ada wasiat itu dan pelaksanaan pembagiannya lebih didahulukan dari pada pelaksanaan wasiat biasa ataupun pembagian warisan.

Dari uraian tentang kedudukan hukum anak angkat maupun orangtua angkat dalam sistem kewarisan di atas, ternyata KHI telah melahirkan sesuatu hukum yang baru yang selama ini tidak pernah dikenal dalam wacana fikih. Pemberian wasiat wajibah kepada anak angkat atau sebaliknya kepada orangtua angkat adalah merupakan jalan terbaik yang ditempuh oleh para ulama penyusun
KHI yang diselaraskan dengan melalui kompromi antara pemikiran fikih yang sangat keras menolak untuk mempersamakan anak angkat dengan anak kandung terutama dalam kaitannya dengan harta warisan di satu sisi, dan pada sisi yang lain adanya kenyataan di masyarakat bahwa tidak sedikit orang yang dalam kehidupan berumah tangga ternyata tidak dikaruniai keturunan yang pada akhirnya mereka mengangkat anak.

KHI tetap menempatkan anak angkat dalam hukum kewarisan sesuai dengan fikih yakni bukan sebagai ahli waris akan tetapi jalan keluarnya tetap dapat bagian dari harta peninggalan orangtua angkatnya dengan melalui wasiat wajibah dengan demikian baik secara filosofis maupun sosiologis pemberian wasiat wajibah kepada anak angkat atau sebaliknya kepada orangtua angkat dapat diterima.

Penguasa maupun hakim tidak dapat memaksa seseorang untuk memberikan wasiat. Adapun kewajiban wasiat bagi seseorang disebabkan keteledorannya dalam memenuhi hak-hak Allah SWT seperti tidak menunaikan haji, tidak membayar zakat, melanggar larangan-larangan berpuasa, dan lain sebagainya yang telah diwajibkan oleh syariat sendiri, bukan oleh penguasa atau oleh hakim

Berbeda dengan hakim sebagai aparat negara yang mempunyai kekuasaan di dalam satu pemerintahan, dalam hal ini hakim mempunyai hak dan wewenang untuk memaksa seseorang memberikan wasiat atau memberikan wasiat atau memberikan surat putusan wajib wasiat yang dikenal dengan istilah "Wasiat Wajibah" kepada orang tertentu dan dalam keadaan tertentu pula.

Kewajiban wasiat bagi seseorang adalah menunaikan kewajiban-kewajiban yang bersangkut paut dengan harta yang belum dilaksanakan sendiri oleh orang yang berwasiat semasa ia masih hidup seperti zakat harta yang belum dibayarkannya, masih mempunyai hutang puasa yang wajib atasnya dan lain-lain sebagainya. Maka wasiat itu wajib dengan ketentuan agama bukan dengan keputusan atau ketetapan hakim.

Seringkali orang ingin mendapatkan bagian yang lebih dalam pembagian harta waris tanpa menghiraukan orang lain yang seharusnya mendapat bagian sabagaimana mestinya. Oleh karena itu, pranata hukum wasiat dalam syariat Islam perlu 
dijadikan pedoman dalam pelaksanannya agar terwujud kemaslahatan anggota keluarga pewaris.

\section{PENUTUP}

\section{Kesimpulan}

Pertama, Hak-hak yang didapat ahli waris yang berbeda agama dengan pewaris adalah hibah, hadiah, wasiat, dan wasiat wajibah. Wasiat wajibah hanya ditemukan dalam pendapat Ibn Hazm yang mengatur tentang ketentuan terhadap seseorang yang telah meninggal dunia dianggap telah memberikan wasiat. Diutamakan kepada kedua orangtua atau kaum kerabatnya yang tidak mewarisi karena mawaris, seperti perbedaan agama dan perbudakan atau karena terhijab oleh ahli waris yang lain.

Kedua, Penegasan Al-Quran Surat Al-Baqarah (2) ayat 180: "bahwa seseorang yang hendak (akan) meninggal dunia wajib berwasiat tentang harta yang dimilikinya." Pendapat Ibn Hazm tentang ayat wasiat tersebut merupakan suatu kewajiban hukum bagi orang Islam untuk berwasiat kepada kerabat dekat yang bukan ahli waris. Jika tidak berwasiat semasa hidupnya, maka pengadilan harus membuat wasiat atas namanya. Ayat ini dijadikan dasar hukum (wajibnya) wasiat wajibah, terutama kepada ahli waris yang terputus hubungannya dengan pewaris.

Ketiga, Besarnya jumlah harta yang dikeluarkan lewat wasiat wajibah untuk saudara kandung non muslim adalah sama dengan bagian saudara kandung muslim yang sederajat. Jika saudara kandung non muslim itu adalah perempuan, maka ia berhak mendapat wasiat wajibah dari harta yang ditinggalkan saudara kandung muslim yang kadar bagiannya sama.

\section{Rekomendasi}

Diharapkan perkawinan berbeda agama dapat membagi harta warisannya kepada ahli waris ketika si pewaris telah meninggal dunia agar ahli waris mendapat bagiannya sesuai dengan kadarnya dan serta adanya wasiat wajibah dapat menurunkan harta si pewaris yang berbeda agama kepada ahli waris yang berbeda agama.

\section{DAFTAR PUSTAKA}

\section{Peraturan Perundang-undangan:}

Burgerlijk Wetboek, diterjemahkan oleh Subekti (PT Dian Rakyat, 2009).

Kompilasi Hukum Islam.

\section{Buku:}

A. Sukris Sarmadi. (1997). Transendensi Keadilan Hukum Waris Islam Transformatif. Jakarta: Raja Grafindo Persada.

Erik Sumarna. (2004). Wasiat Wajibah Terhadap Saudara Kandung. Medan: Program Pascasarjana IAIN Sumatera Utara.

Fathur Rahman. (1994). Ilmu Waris. Bandung: Almaatif.

Moh. Machfudin Aladip. Terjemah Bulughul Maram. Karya Besar Alhafizh Ibn Hajar Al. Asqoalani. Semarang: Karya Toha Putra.

M. Idris Ramulyo. (1992). Perbandingan Hukum Kewarisan Islam Menurut Undnag-Undang Hukum Perdata (BW) di Pengadilan Negeri (Suatu Studi Kasus). Jakarta: Pedoman Ilmu Jaya.

Mughniyah, dkk. (2004). Fiqih Lima Mazhab. Jakarta: Lentera.

R. Subekti dan R. Tjitrisudibio. (1960). Kitab Undang-Undang Hukum Perdata. Jakarta: Paramita.

Ramlan Yusuf Rangkuti. (1987). Pengantar Hukum Islam. Medan: Fak. Hukum USU-UISU.

Suparman Usman. (2001). Hukum Islam. Jakarta: Gaya Media Pratama.

Yayasan Penyelenggara Penterjemah Alquran. (1980). Alquran dan Terjemahannya. Jakarta: Departemen Agama RI.

Zainuddin Ibn Abd al- Aziz. (1979). Fath al-Mu in, Terj. Ali as ad. Kudus: Menara kudus.

Komite Fakultas Syariah Universitas Al Azhar. (2000-2001). Ahkamul-Mawarist fil-FiqhilIslami. Mesir: Penerbit Maktabah ar-Risalah ad Dauliyyah. 